Nur Endah Hikmah Fauziyah $^{1}$

\section{DAMPAK POSITIF EVALUASI PEMBELAJARAN TERHADAP PRESTASI BELAJAR SISWA KELAS 4 SD NEGERI BLOTONGAN 03 JAWA TENGAH TAHUN PELAJARAN 2018/2019}

\begin{abstract}
Abstrak
Tujuan dari penelitian ini adalah untuk mengetahui dampak positif evaluasi pembelajaran terhadap prestasi belajar siswa kelas 4 SD Negeri Blotongan 03. Jenis penelitian yang digunakan dalam penelitian ini adalah penelitian kuantitatif dengan menggunakan metode studi kasus. Kemudian dituangkan dalam bentuk diskripsi. Sampel dari penelitian ini adalah siswa kelas 4 SDN Blotongan 03 semester genap tahun pelajaran 2018/2019 yaitu berjumlah 30 . Instrumen dalam penelitian ini antara lain yaitu observasi, kuesioner, angket, cacatan lapangan, dokumentasi dan wawancara. Kemudian dianalisis dengan menggunakan data kuantitatif yaitu dengan menjumlahkan hasil kuesioner disetiap nomornya. Hasil penelitian diperoleh bahwa melalui berbagai macam evaluasi pembelajaran yang dilakukan guru terhadap siswa kelas 4 SD Negeri Blotongan 03 menunjukkan hasil yang berdampak positif dalam cakupan 4 ranah pendidikan yaitu kognitif, spiritual, afektif, dan psikomotor.
\end{abstract}

Kata Kunci: Evaluasi Pembelajaran, Prestasi Belajar Siswa.

\begin{abstract}
The purpose of this study was to determine the positive impact of learning evaluation on the learning achievement of $4^{\text {th }}$ grade students of SD Negeri Blotongan 03. The type of research used in this study is quantitative research. In this study using descriptive methods. The sample of this study is $4^{\text {th }}$ grade student of SD Negeri Blotongan 03 even semester of the school year 2018/2019 which is thirty. The instruments in this study included observation, questionnaires, field notes, and interviews. Then analyzed using quantitative data, namely bi summing the result of the questionnaire in each number. The results of the study obtained that through various kinds of evaluations of learning carried out by teacher for $4^{\text {th }}$ grade students of SD Negeri Blotongan 03 show result that have a positive impact in the scope of 4 eduction domain, namely cognitive, spiritual, affective, and psychomotor.
\end{abstract}

Keywords: Evaluation Of Learning, Student Achievement.

\footnotetext{
${ }^{1}$ Pendidikan Guru Sekolah Dasar, Fakultas Keguruan dan Ilmu Pendidikan, Universitas Kristen Satya Wacana

Alamat email 292016154@student.uksw.edu
} 


\section{PENDAHULUAN}

Prestasi belajar pada umumnya berkenaan dengan aspek pengetahuan dalam rangka mencapai usaha belajar. Prestasi belajar suatu masalah yang bersifat abadi dalam sejarah kehidupan manusia, karena sepanjang rentang kehidupannya manusia akan selalu mengejar prestasi menurut kemampuan masing-masing. Maka betapa pentingnya guru harus mengetahui dan memahami prestasi peserta didik, sebab fungsi prestasi belajar sebagai indikator keberhasilan dalam dunia pendidikan tetapi juga sebagai umpan balik bagi guru dalam melaksanakan proses pembelajaran sehingga dapat menentukan apakah perlu diagnosis, penempatan, tindak lanjut atau bimbingan terhadapat peserta didik.

Sebagaimana yang dikemukakan oleh Cronbach dalam (Zainal Arifin, 2013:13), mengatakan bahwa kegunaan prestasi belajar ada beberapa macam, antara lain : sebagai umpan balik guru terhadap peserta didik dalam mengajar, untuk mengetahui kesulitan belajar peserta didik, untuk keperluan bimbingan dan penyuluhan, untuk keperluan pemilihan, untuk penempatan atau penjuruan,untuk menentukan isi kurikulum, dan untuk menentukan kebijakan sekolah. Suatu proses pembelajaran tentunya guru dengan siswa saling berinteraksi dan salah satu langkah yang harus ditempuh guru adalah melakukan evaluasi pembelajaran. Evaluasi pembelajaran sangat penting dilakukan guru karena melalui evaluasi pembelajaran guru dapat mengukur tingkat kemampuan peserta didik, tetapi juga untuk mengetahui keefektifan dan efisiensi sistem pembelajaran.

Berdasarkan hasil wawancara dengan guru kelas 4 di SD Negeri Blotongan 03, mengatakan bahwa "evaluasi pembelajaran memang sangat penting dilakukan, karena dapat mengukur sejauh mana kemampuan siswa, selain itu juga untuk menilai secara keseluruhan dalam 4 ranah pendidikan yaitu aspek kognitif, spiritual, afektif, dan psikomotor. Kemudian untuk mencapai hasil evaluasi ada banyak cara yang dapat dilakukan oleh guru, antara lain melalui Tanya jawab lisan atau umpan balik pembelajaran, tes pilihan ganda serta uraian, atau membuat sebuah karya. Dengan melakukan beberapa hal tersebut pada akhirnya guru dapat mengetahui prestasi masingmasing siswa dan dapat mengukur ketercapaian dalam mengajar". Temuan ini mendukung pendapat Anne Anastasi dalam Saifuddin Anwar, (2011:3) menyatakan bahwa melalui tes pada dasarnya merupakan suatu pengukuran yang objektif dan standard terhadap sampel perilaku seseorang dalam mencapai keberhasilan. Sedangkan 
tes menurut Goodenough dalam Anas Sudijono, (2011:67) merupakan suatu serangkaian tugas yang diberikan kepada individu atau kelompok, dengan tujuan untuk membandingkan kecakapan mereka satu sama yang lain.

Berdasarkan uraian latar belakang diatas, rumusan masalah dalam penelitian ini adalah apakah dampak positif evaluasi pembelajaran terhadap prestasi belajar siswa kelas 4 di SD Negeri Blotongan 03?. Adapun tujuan dalam penelitian ini yaitu untuk mengetahui dampak positif evaluasi pembelajaran terhadap prestasi belajar siswa kelas 4 di SD Negeri Blotongan 03. Penelitian ini juga memberikan manfaat bagi peserta didik dan guru antara lain yaitu pertama, manfaat bagi peserta didik setelah melakukan evaluasi pembelajaran dalam ranah kognitif (pengetahuan) antara lain: siswa dapat mengukur daya ingat serta kemampuan dalam mengikuti pembelajaran yang telah disampaikan guru, siswa dapat mengetahui letak kekurangannya dalam memahami materi pembelajaran tertentu. Kedua, manfaat bagi peserta didik setelah melakukan evaluasi pembelajaran dalam ranah afektif (sikap) antara lain: siswa dapat beretika dengan lebih baik dalam menyampaikan perkataan ataupun pendapat melalui evaluasi pembelajaran dengan cara tanya jawab lisan, melalui evaluasi pembelajaran dapat meningkatkan kerjasama serta interaksi antara guru dengan siswa dan antara siswa dengan siswa, siswa menjadi lebih berani mengemukakan pendapatnya melalui evaluasi pembelajaran dengan cara tanya jawab lisan serta dengan cara umpan balik pembelajaran yang telah diikuti siswa, setelah mengetahui hasil evaluasi belajarnya melalui tes tertulis siswa menjadi tau letak kurang paham dalam menerima materi pembelajaran oleh karena itu siswa menjadi lebih giat belajar untuk meningkatkan hasil belajarnya. Kemudian juga dapat bekerjasama dengan orangtua untuk membahas serta menyelesaikan tugas yang telah diberikan oleh guru. Ketiga, manfaat bagi peserta didik setelah melakukan evaluasi pembelajaran dalam ranah spiritual (religius) antara lain: menambah rasa syukur kepada Tuhan YME karena dapat meningkatkan kemampuan daya ingat belajarnya dan dapat melakukan evaluasi pembelajaran dengan baik. Keempat, manfaat bagi peserta didik setelah melakukan evaluasi pembelajaran dalam ranah psikomotor (ketrampilan) antara lain: siswa dapat menerapkan materi yang telah disampaikan oleh guru dalam kehidupan sehari-hari. Kelima, manfaat bagi guru setelah melakukan evaluasi pembelajaran, antara lain: dapat mengukur tingkat kemampuan peserta didik dari berbagai ranah pendidikan dengan menggunakan acuan penilaian 
yang telah ditentukan, dapat mengukur tingkat ketercapaian tujuan pembelajaran, dan dapat mengukur tingkat efisien serta efektif pembelajaran.

\section{METODE}

Penelitian ini dengan menggunakan pendekatan kuantitatif dengan metode studi kasus. Penelitian ini dianalisis dengan menggunakan data kuantitatif yaitu dengan menjumlahkan hasil kuesioner disetiap nomornya. Kemudian dituangkan dalam bentuk diskripsi. Penelitian ini dilaksanakan di kelas 4 SD Negeri Blotongan 03 semester genap tahun pelajaran 2018/2019 Kecataman Sidorejo Kota Salatiga dengan menggunakan kuesioner setelah siswa melakukan evaluasi pembelajaran. Subjek dalam penelitian ini adalah para siswa kelas IV SD Negeri Blotongan 03. Para siswa kelas IV SD Negeri Blotongan 03 dijadikan subjek penelitian utama dan sumber informan kunci, karena siswa menjadi peran utama yang aktif merespon seluruh kegiatan pembelajaran khususnya dalam melakukan evaluasi pembelajaran yang diberikan guru.

Variabel dalam penelitian ini terdiri dari variabel $\mathrm{X}$ atau variabel bebas yaitu dampak positif evaluasi pembelajaran. Sedangkan variabel $\mathrm{Y}$ atau variabel terikat dalam penelitian ini ialah prestasi belajar siswa. Penelitian ini menjadi instrumen penelitian karena peneliti merupakan instrumen yang efektif untuk mengumpulkan data. Berjalannya penelitian, peneliti dibantu dengan menggunakan instrumen panduan seperti panduan observasi (pengamatan), pedoman wawancara, lembar angket, catatan lapangan dan juga dokumentasi. Teknik analisis data dilakukan sesuai dengan prosedur ilmiah penelitian kualitatif. Data dihasilkan dari proses pengamatan atau observasi, wawancara, dokumentasi-dokumentasi yang telah dicatat, catatan lapangan, dan kuesioner atau beberapa pengajuan pertanyaan.

\section{HASIL DAN PEMBAHASAN}

Guru dalam hal penyampaian materi hendaknya dapat menciptakan suasana yang menyenangkan, kondusif, aktif, kreatif serta menyiapkan alat-alat dan perlengkapan pembelajaran, dan menentukan teknik penilaian. Sehingga pada akhir pembelajaran guru dalam melakukan evaluasi pembelajaran dapat memperoleh informasi berupa karakteristik peserta didik 4 ranah pendidikan yaitu kognitif (pengetahuan dan intelektual), spiritual(religius), afektif (sikap, minat, dan motivasi), dan psikomotor (ketrampilan, gerak, dan tindakan). Dengan demikian, guru dapat mengukur 
ketercapaian tujuan pembelajaran melalui hasil belajar siswa. Temuan ini mendukung pendapat Benyamin Bloom dalam Nana Sudjana(2010:22) yang mengatakan bahwa secara garis besar membagi klasifikasi hasil belajar menjadi tiga ranah yaitu ranah kognitif, ranah afektif, dan ranah psikomotor. Dalam memperoleh informasi guru dapat mengevaluasi secara lisan, tertulis, atau perbuatan. Jika guru dapat melakukan evaluasi dengan sistematis. Dengan demikian tentunya guru akan memperoleh dampak positif evaluasi pembelajaran terhadap prestasi belajar siswa kelas 4 di SD Negeri Blotongan 03. Berikut hasil penilitian kelas 4 di SD Negeri Blotongan 03 :

\section{Tabel Hasil Penelitian}

\section{kelas 4 di SD Negeri Blotongan 03 Tahun Pelajaran 2018/2019}

\begin{tabular}{|l|l|l|l|l|l|l|}
\hline No. & Pernyataan & \multicolumn{3}{l|}{ Kategori Jawaban } \\
\cline { 3 - 6 } & & SS & S & R & TS & STS \\
\hline 1. & $\begin{array}{l}\text { Sebelum guru melakukan evaluasi pembelajaran, saya kurang } \\
\text { paham tentang materi yang telah disampaikan. }\end{array}$ & 15 & 7 & 8 & \\
\hline 2. & $\begin{array}{l}\text { Sesudah melakukan evaluasi pembelajaran, saya dapat } \\
\text { mengukur daya ingat saya terhadap pembelajaran yang telah } \\
\text { saya ikuti. }\end{array}$ & 21 & 9 & & & \\
\hline 3. & $\begin{array}{l}\text { Setelah guru melakukan evaluasi pembelajaran saya dapat } \\
\text { mengukur kemampuan dalam mengikuti pembelajaran. }\end{array}$ & 10 & 20 & & & \\
\hline 4. & $\begin{array}{l}\text { Saya senang ketika guru melakukan evaluasi karena dapat } \\
\text { mempererat kerjasama dan interaksi antar teman sekelas. } \\
\text { Misalnya saling Tanya jawab antar teman atau antar kelompok. }\end{array}$ & 13 & 17 & & & \\
\hline 5. & $\begin{array}{l}\text { Evaluasi pembelajaran dapat meningkatkan interaksi antara guru } \\
\text { dengan siswa melalui Tanya jawab lisan. }\end{array}$ & 15 & 15 & & & \\
\hline 6. & $\begin{array}{l}\text { saya sangat suka jika setiap akhir pembelajaran guru melakukan } \\
\text { evaluasi pembelajaran karena sebagai umpan balik terhadap saya } \\
\text { dalam mengikuti pembelajaran. }\end{array}$ & 17 & 12 & 1 & & \\
\hline 7. & $\begin{array}{l}\text { Menurut saya evaluasi pembelajaran sangat efektif karena dapat } \\
\text { mengukur tujuan pembelajaran yang lebih baik. }\end{array}$ & 16 & 14 & & & \\
\hline 8. & $\begin{array}{l}\text { Dengan evaluasi pembelajaran saya menjadi lebih tau cara } \\
\text { bertanya kepada guru dengan bahasa yang benar dan sopan. }\end{array}$ & 25 & 5 & & & \\
\hline 9. & $\begin{array}{l}\text { Dengan evaluasi pembelajaran menambah rasa syukur kepada } \\
\text { Tuhan YME karena dapat menunjukkan saya dalam } \\
\text { meningkatkan kemampuan daya ingat belajar. }\end{array}$ & 22 & 8 & & & \\
\hline 10. & $\begin{array}{l}\text { Dengan evaluasi pembelajaran saya menjadi berani } \\
\text { mengemukakan pendapat melalui Tanya jawab lisan. }\end{array}$ & 10 & 20 & & \\
\hline 11. & $\begin{array}{l}\text { Setelah mengikuti evaluasi pembelajaran saya dapat menerapkan } \\
\text { materi yang telah disampaikan oleh guru dalam kehidupan } \\
\text { sehari-hari. Contoh: mengamalkan sila pertama Pancasila yaitu } \\
\text { beribadah kepada Tuhan YME. }\end{array}$ & $\begin{array}{l}\text { Setelah mengetahui hasil evaluasi pembelajaran, saya menjadi } \\
\text { lebih giat belajar. }\end{array}$ & 22 & 8 & & \\
\hline 13. & $\begin{array}{l}\text { Dengan evaluasi pembelajaran saya menjadi tau letak } \\
\text { kekurangan saya dalam memahami materi pembelajaran tertentu. }\end{array}$ & 9 & 20 & 1 & & \\
\hline
\end{tabular}




\begin{tabular}{|l|l|l|l|l|l|l|}
\hline 14. & $\begin{array}{l}\text { Saya sangat senang ketika guru memberikan reward / } \\
\text { penghargaan atas hasil belajar saya karena akan menambah } \\
\text { semangat belajarku. }\end{array}$ & 73 & 7 & & \\
\hline 15. & $\begin{array}{l}\text { Setelah mengikuti evaluasi pembelajaran saya dapat } \\
\text { bekerjasama dengan orang tua untuk membahas tugas yang telah } \\
\text { diberikan oleh guru. }\end{array}$ & 19 & 9 & 1 & 1 & \\
\hline
\end{tabular}

Berdasarkan hasil penelitian di kelas 4 SD Negeri Blotongan 03, bahwa kuesioner nomor 1 menghasilkan 15 siswa yang memilih Setuju 7 siswa yang memilih Ragu 8 siswa yang memilih Tidak Setuju kuesioner nomor 2 menghasilkan 21 siswa yang memilih Sangat Setuju 9 siswa yang memilih Setuju, kuesioner nomor 3 menghasilkan 10 siswa yang memilih Sangat Setuju 20 siswa yang memilih Setuju, kuesioner nomor 4 menghasilkan 13 siswa yang memilih Sangat Setuju 17 siswa yang memilih Setuju, kuesioner nomor 5 menghasilkan 15 siswa yang memilih Sangat Setuju, 15 siswa yang memilih Setuju, kuesioner nomor 6 menghasilkan 17 siswa yang memilih Sangat Setuju 12 siswa yang memilih Setuju 1 siswa yang memilih Ragu, kuesioner nomor 7 menghasilkan 16 siswa yang memilih Sangat Setuju 14 siswa yang memilih Setuju, kuesioner nomor 8 menghasilkan 25 siswa yang memilih Sangat Setuju 5 siswa yang memilih Setuju, kuesioner nomor 9 menghasilkan 22 siswa yang memilih Sangat Setuju 8 siswa yang memilih Setuju, kuesioner nomor 10 menghasilkan 10 siswa yang memilih Sangat Setuju 20 siswa yang memilih Setuju, kuesioner nomor 11 menghasilkan 22 siswa yang memilih Sangat Setuju 8 siswa yang memilih Setuju, kuesioner nomor 12 menghasilkan 22 siswa yang memilih Sangat Setuju, 8 siswa yang memilih Setuju, kuesioner nomor 13 menghasilkan 9 siswa yang memilih Sangat Setuju 20 siswa yang memilih Setuju 1 siswa yang memilih Ragu, kuesioner nomor 14 menghasilkan 23 siswa yang memilih Sangat Setuju 7 siswa yang memilih Setuju, kuesioner nomor 15 menghasilkan 19 siswa yang memilih Sangat Setuju 9 siswa yang memilih Setuju 1 siswa yang memilih Ragu 1 siswa yang memilih Tidak Setuju.

Berdasarkan uraian hasil penelitian dengan menggunakan kuesioner diatas bahwa sebelum guru melakukan evaluasi pembelajaran ada beberapa siswa yang belum dapat memahami bagian materi tertentu. Namun setelah guru melakukan evaluasi pembelajaran siswa dapat memahami materi pembelajaran lebih baik. Terkait dari aspek kognitif masing-masing siswa dapat mengukur dan mengetahui tingkat pemahaman terhadap materi yang telah disampaikan oleh guru. Salah satu hal yang dilakukan guru 
dalam evaluasi pembelajaran yaitu umpan balik materi yang disampaikan terhadap siswa dengan cara Tanya jawab lisan. Melalui Tanya jawab lisan antara guru dengan siswa dapat berinteraksi dengan bahasa yang benar dan sopan serta siswa menjadi berani untuk mengemukakan pendapatnya seperti contoh: berani untuk mempresentasikan hasil diskusi kelompok di depan teman sekelas. Dengan demikian melalui evaluasi pembelajaran dapat melatih serta meningkatkan aspek afektif atau sikap siswa dalam merespon kegiatan pembelajaran.

Hasil yang diperoleh adalah siswa begitu sangat senang ketika guru memberikan reward/penghargaan terhadap hasil belajar dan mengetahui hasil evaluasi nilainya bagus. Tentunya hal itu sangat berdampak positif bagi siswa karena siswa jadi lebih giat belajar. Selain itu terkait aspek spiritual atau religious, siswa juga tidak lupa bersyukur kepada Tuhan YME karena telah diberi daya ingat belajar yang baik sehingga dapat meningkatkan prestasi belajarnya. Dengan diberikan daya ingat yang baik hendaknya siswa dapat menerapkan materi pelajaran dalam kehidupan sehari-hari. Misalnya: menerapkan sila ke 1 dalam Pancasila yaitu salah satunya ingat bersyukur atas segala nikmat yang diberikan Tuhan YME. Sehingga siswa dapat mencapai aspek psikomotor lebih baik.

Kerjasama antara siswa dengan orangtua di dalam jenjang pendidikan memang sangat penting karena bertujuan untuk membentuk karakter anak lebih baik serta meninjau dari seluruh aspek baik dari segi kepribadian anak itu sendiri berkaitan dengan prestasi di sekolah maupun dari segi bergaul dengan teman sebaya. Oleh karena itu di dalam kerangka Kurikulum 2013 sekarang dicantumkan pada akhir kegiatan pembelajaran yaitu siswa diberi tugas untuk dibahas bersama orangtua di rumah.

\section{SIMPULAN}

Berdasarkan hasil penelitian dapat disimpulkan bahwa berbagai macam evaluasi pembelajaran yang dilakukan guru sangat berdampak positif terhadap prestasi belajar siswa kelas 4 SD Negeri Blotongan 03. Terutama juga dapat mengukur tingkat kemampuan siswa kelas 4 SD Negeri Blotongan 03. Adapun saran dalam penelitian ini yaitu guru harus lebih kreatif dalam mengolah suasana kelas karena berkaitan dengan kurikulum 2013 yang menuntut siswa lebih aktif. Sehingga jika guru dapat menciptakan suasana kelas yang menyenangkan, tentunya peserta didik akan dapat aktif dalam mengikuti pembelajaran dengan lebih baik. 


\section{DAFTAR PUSTAKA}

Arifin, Zaenal. (2013). Evaluasi Pembelajaran. Bandung: PT. Remaja Rosdakarya.

Ghullam Hamdu, L. A. (2011). PENGARUH MOTIVASI BELAJAR SISWA TERHADAP PESTASI BELAJAR IPA. jurnal penelitian pendidikan , 83.

Trisnamansyah, S. (2015). Evaluasi Pembelajaran. Bandung: Pustaka Setia Bandung.

Febru, Erna. (2011). Asesmen dan Evaluasi. Malang: Aditya Media Publishing.

Sudjana, N. (2010). Penilaian Hasil Proses Belajar Mengajar. Bandung: PT.

Remaja Rosdakarya.

Sudijono, A. (2011). Evaluasi Pendidikan. Jakarta: PT. Raja Grafindo Persada.

Azwar, S. (2011). Tes Prestasi. Yogyakarta: Pustaka Pelajar. 